\title{
Validation of the complexity index method at three manufacturing companies
}

\author{
Sandra Mattsson ${ }^{1}$, Åsa Fasth ${ }^{2}$, Johan Stahre ${ }^{5}$, \\ Malin Karlsson ${ }^{6}$ \\ Chalmers University of Technology, Hörsalsvägen 7A, SE- \\ 41481 \\ Gothenburg, Sweden \\ ${ }^{1}$ sandra.mattsson@chalmers.se
}

\author{
Kerstin Dencker ${ }^{3}$, Per Gullander ${ }^{4}$ \\ Swerea IVF, Box 104, SE-431 22 \\ Mölndal, Sweden \\ Anna Davidsson ${ }^{7}$ \\ Volvo Car Corporation, SE-405 31 \\ Gothenburg, Sweden
}

\begin{abstract}
In order to manage increasing numbers of product variants, tools that can reduce or manage production complexity are vital. The paper describes CompleXity Index (CXI), an indexbased method and tool that assess the complexity at an industrial workstation. CXI was validated at three Swedish manufacturing companies investigating how different roles affect the index calculation and if the method measures what was intended. In all three cases, CXI was seen as a useful tool that provided a holistic view of the problems seen at a station. In addition it was indicated that complexity and unbalanced work was connected and that the method could be used to predict problem areas on new stations.
\end{abstract}

Keywords-Perceived production complexity; final assembly; case study; production planning; industrial competitiveness; managing complexity; validation.

\section{COMPLEXITY INDEX}

Today increased complexity is still one of the biggest challenges in manufacturing [1]. Manufacturing industry experience an increasing number of product variants, components, product mix, and frequent changes in volume, process, product, and organization. In order to manage these challenges, it is vital for industry to be able to reduce or manage pro-duction complexity. People working with production engi-neering, operation, or introducing changes need to better understand and visualize what level of production complexity they experience. Further, industry needs to have tools to identify what type of improvements that can be made to reduce complexity.

To meet the apparent need to measure production complexity, a CompleXity Index (CXI) was developed within the project COMPLEX. CXI is a question-naire-based method and assessment tool that includes 26 statements addressing the following identified problem areas: Product variants, Work content, Layout, Tools and support tools, Work instructions and General view of the station. The problem areas are based on empirical work by Fässberg et al., [2] and Gullander et al., [3] (the development of CXI is found in Mattsson et al., [4]). The questionnaire statements in CXI are of Likert-type, and evaluated as part of a formula (see Mattsson et al., [4]). The output of the formula is a complexity index that establishes a measurement for the complexity of a station. In addition the median answers from each of the problem areas are presented as a color-carpet. The objective of CXI is to assess the complexity level at a station i.e. low, middle or high complexity (visualized by the respective colors: green, yellow or red). This can be used in several ways e.g. to improve stations and plan production.

The aim of this paper is to investigate the usefulness of $\mathrm{CXI}$ and to test its validity.

\section{VALIDATION THROUGH TRIANGULATION}

In this paper an applied research methodology is used, which means that empirical data from industrial case studies are a major part of the research results. To validate the proposed CXI method, a triangulation approach [5] was used. In this paper investigator and data triangulation was used suggested Deniz [6] (Deniz also suggested two other types of triangulations).

TABLE I. TYPES OF USERS IN THE INVESTIGATOR TRIANGULATION

\begin{tabular}{lll}
\hline Company & $\begin{array}{l}\text { Gathering CXI } \\
\text { questionnaires }\end{array}$ & $\begin{array}{l}\text { Performing } \\
\text { analysis }\end{array}$ \\
\hline A & Novice users & Expert users \\
B & Novice users & Expert users \\
C & Novice users & Users \\
\hline
\end{tabular}

Data triangulation is the use of multiple sources, i.e. different participants are asked the same thing. In these studies different types of data sources were used: operators, logistical personnel, trainers, a production supervisor, the head of competence-assurance and higher official and heads (see Table II). In this table the types of companies, Company A-C, are also presented. The validation of CXI includes three cases where the feasibility and outcome of the method is tested and investigated. 
TABLE II. DATA SOURCES: THE RESPONDENTS AND PERSONNEL PART OF DISCUSSING THE RESULTS OF CXI

\begin{tabular}{|c|c|c|c|}
\hline Company & $\begin{array}{l}\text { Type of } \\
\text { company }\end{array}$ & Respondents & $\begin{array}{l}\text { Part of } \\
\text { analysing } \\
\text { results }\end{array}$ \\
\hline $\mathbf{A}$ & $\begin{array}{l}\text { Large } \\
\text { automotive } \\
\text { company }\end{array}$ & $\begin{array}{l}4 \text { operators } \\
\text { (2 stations) }\end{array}$ & $\begin{array}{l}4 \text { operators and } \\
1 \text { production } \\
\text { supervisor } \\
\text { separately }\end{array}$ \\
\hline $\mathbf{B}$ & $\begin{array}{l}\text { Large } \\
\text { automotive } \\
\text { company }\end{array}$ & $\begin{array}{l}12 \text { operators and } \\
3 \text { trainers } \\
\text { ( } 3 \text { stations })\end{array}$ & $\begin{array}{l}\text { Head of } \\
\text { competence- } \\
\text { assurance }\end{array}$ \\
\hline $\mathbf{C}$ & $\begin{array}{l}\text { Medium sized } \\
\text { company } \\
\text { making } \\
\text { electronic } \\
\text { components }\end{array}$ & $\begin{array}{l}4 \text { kit operators } \\
\text { and } 10 \text { logistics } \\
\text { personnel } \\
\text { (11 stations) }\end{array}$ & $\begin{array}{l}\text { An operator } \\
\text { representative, } \\
\text { higher officials } \\
\text { and department } \\
\text { heads. }\end{array}$ \\
\hline
\end{tabular}

The case study contained semi-structured interviews and discussions with affected personnel regarding the outcome of CXI (both the measurement index and visualization using the colour-carpet). In all cases, the respondents completed their questionnaire in their own time and there was a $100 \%$ response rate.

\section{CORRECTNESS OF CALCULATION, USAGE AS A PREDICTION TOOL AND THE VIEW OF DIFFERENT ROLES}

The validation was made at three manufacturing Companies A-C with different study focuses: Correctness of the calculation, usage as a prediction tool and the view of different roles. In this chapter the result and discussion is presented.

Whether the CXI calculation was performed correctly or not was investigated at Company $\mathrm{A}$, by interviewing the respondents. Two specific stations were chosen for CXI testing at Company A, based on an previous assessment of CXI indicating that the stations had high complexity (see stations $\mathrm{F}$ and $\mathrm{H}$ in Mattsson et al., [7]). In the new assessment, the stations were rated as complex due to two problem areas: Product variants and Layout. The respondents stated that the station should be given a red complexity index. Although the operators thought that the station was acceptable to work at, they said that a new person would have difficulty to learn the work and other stations were more difficult for them. The production supervisor also believed the CXI calculation was correct. He however stated that the measurement did not give him new information (in addition he was not given resources to perform any big changes). Instead, he thought the method could be useful on a higher management level.

At Company B, the CXI tool was used to predict problems in future stations by studying similar already existing stations. 26 respondents assessed three stations and the main problem area, indicated by CXI, was Production variants. Al-most all personnel perceived the tools and support tools to be green, but some improvement suggestions were given. Improvement suggestions included work instructions (station 1), sequencing, pre-work and handling of material (station 2), lifting and narrow work place (station 3). The results were considered useful to the company, since it reflected previously unknown facts.

The view of different roles was investigated at both Company $\mathrm{B}$ and Company $\mathrm{C}$ by studying differences between operators and trainers and the views of kit assembly personnel and logistics personnel respectively. The trainers' role at Company B was to teach new trainers how to educate their personnel on the lines i.e. had deeper knowledge of the station but had not worked there for some years. Results indicate that trainers rated the stations as more complex than the actual operators did. However, stations $\mathrm{A}$ and $\mathrm{C}$ had values close to red values $(\mathrm{CXIA}=2.96$ and $\mathrm{CXIC}=2.90$, see score boundaries in Table III), see Table IV.

TABLE III. SCORE BOUNDARIES FOR CXI

\begin{tabular}{llll}
\hline CXI & Complexity & Colour & Action \\
\hline$<2$ & Low & g (Green) & No action needed \\
\cline { 2 - 2 } 2 and $<3$ & Middle & $\mathbf{y}$ (Yellow) & Need change \\
$\bullet 3$ & High & R (Red) & $\begin{array}{l}\text { Need urgent } \\
\text { change }\end{array}$ \\
\hline
\end{tabular}

TABLE IV. COLOR-CARPET FOR TRAINERS AND OPERATORS AT COMPANY B

\begin{tabular}{|c|c|c|c|c|c|c|}
\hline Problem area & $\begin{array}{l}\text { Station A } \\
\text { Trainers }\end{array}$ & Operators & $\begin{array}{l}\text { Station B } \\
\text { Trainers }\end{array}$ & Operators & $\begin{array}{l}\text { Station C } \\
\text { Trainers }\end{array}$ & Operators \\
\hline Product variants & $\mathrm{R}$ & $\mathrm{R}$ & $\mathrm{R}$ & $\mathbf{y}$ & $\mathrm{R}$ & $\mathbf{y}$ \\
\hline Work content & $\mathbf{y}$ & $\mathrm{g}$ & g & $\mathbf{y}$ & $\mathbf{y}$ & $\mathrm{g}$ \\
\hline Layout & $\mathbf{y}$ & $\mathbf{y}$ & $\mathbf{y}$ & $\mathbf{y}$ & $\mathrm{R}$ & $\mathbf{y}$ \\
\hline $\begin{array}{l}\text { Tools and support } \\
\text { tools }\end{array}$ & g & $\mathrm{g}$ & $\mathrm{g}$ & $g$ & $\mathbf{y}$ & g \\
\hline Work instructions & g & $\mathbf{y}$ & g & $\mathbf{y}$ & $\mathbf{y}$ & $\mathbf{y}$ \\
\hline General & $\mathbf{y}$ & $\mathbf{y}$ & $\mathbf{g}$ & $\mathbf{y}$ & $\mathbf{y}$ & $\mathbf{y}$ \\
\hline CXI & $\begin{array}{r}\mathrm{R} \\
3.58 \\
\end{array}$ & у 2.96 & y 2.63 & $\begin{array}{r}\mathrm{R} \\
3.38 \\
\end{array}$ & R 3.67 & у 2.90 \\
\hline
\end{tabular}


The difference could however be due to that they had not worked on the station for some time. In order to further understand the problems identified, a discussion with the associated operators is needed. CXI was considered useful as a first step in that discussion. In addition CXI does not capture connections be-tween red values in product variants and support tools (see Fig.1.). In these stations there are a lot of product variants, which was at the station secured via sup-port tools. The tools make it hard and almost impossible to assembly it incorrectly. This characteristic could be included with a complimentary statement.

At Company $\mathrm{C}$, eleven stations were assessed. Studies were made in order to reduce and understand time and work carried out that was not included in the balance, i.e. unbalanced time at the stations. Both operators and logistics personnel were included in the study to get a more holistic view of the stations. Three types of stations were studied: a kitting station, the assembly train, and four assembly stations. It was indicated that perceived complexity was proportional to the unbalanced work and the stations were mainly complex in the following problem areas: Product variants, Work content and Layout. The station that had the highest index had unbalanced work ranging from 56-61\% [8] and the common unbalanced work was listed as: rework, repeated movement of the operators from station to material rack, and waiting time. Results were presented to Company C's operator representative, higher officials, and department heads who thought that the results were useful, since it gave detailed insight on where there are problems with unbalanced work. In addition the colourcarpet was seen as a good basis for discussion since it helped their view of how to improve the process and quality of the system and how to prioritize future actions. The index also coincided with their perceived view of the station.

\section{CONCLUSION}

The method, CompleXity Index (CXI), was in all industrial cases seen as a useful tool for understanding the perceived production complexity at a station. It was found that CXI measures what it was intended to measure. The results cannot be generalized, since three different types of cases were used. The following indications were seen:

- At Company A the operators were satisfied with the assessment and its usefulness. The problems however, were already known through other company processes and the production supervisor did not have the resources to perform changes, therefore the CXI results were not seen as giving an added value.

- At Company B, CXI provided a view of complexity that could be useful when building or redesigning workstations. It was also seen that the relation between product variants and tools and support tools in CXI needs further work.
- At Company $\mathrm{C}$ a connection between unbalanced work and complexity was seen.

In addition it was seen that the results from different roles should be interpreted together with the personnel. Future work includes further studying the benefits of using the method.

\section{ACKNOWLEDGEMENT}

The authors gratefully acknowledge the Swedish Governmental Agency for Innovation Systems, Vinnova, for funding from the research programme Production Strategies and Models for Product Realization. The project is carried out in collaboration between Swerea IVF, Chalmers University of Technology, Volvo Car Corporation, Electrolux, Stoneridge Electronics, and AB Volvo. The project has been carried out within the framework of the Sustainable Production Initiative, and the Production Area of Advance at Chalmers.

\section{REFERENCES}

[1] W. ElMaraghy, H. ElMaraghy, T. Tomiyama, and L. Monostori, "Complexity in engineering design and manufacturing," CIRP Annals - Manufacturing Technolocy,vol.61 pp. 793-814, 2012.

[2] T. Fässberg, U. Harlin, K. Garmer, P. Gullander, Å. Fasth, S Mattsson, K. Dencker, A. Davidsson, and J. Stahre, "An Empirical Study Towards a Definition of Production Complexity," in 21st International Conference on Production Research (ISAM), Stuttgart, Germany, 2011.

[3] J. Ha, S. Choi, S Shin, K Chwa, and S. Chang, On deciding 3D part disassemblability and surface machinability, IIE Transactions, vol.28, pp.847-854, 1996

[4] P. Gullander, A. Davidsson, K. Dencker, Å. Fasth, U. Harlin, and J. Stahre, "Towards a Production Complexity Model that Supports Operation, Re-balancing and Man-hour Planning," in 4th Swedish Production Symposium (SPS), Lund, Sweden, 2011.

[5] S. Mattsson, P. Gullander, and A. Davidsson, "Method for Measuring Production Complexity " presented at the International Manufacturing Conference IMC 28 - Manufacturing Sustainability, Dublin City University, Ireland, 2011.

[6] W. Olsen, Developments in sociology (Ch. 4 Triangulation in social research: Qualitative and quantitative methods could really be mixed), 2004.

[7] N. K. Dezin, The researh act: A theoretical introduction to sociological methods. Chicago: Aldine, 1970.

[8] S. Mattsson, P. Gullander, U. Harlin, G. Bäckstrand, Å. Fasth, and A. Davidsson, "Testing Complexity Index - a Method for Measuring Perceived Production Complexity," in 45th Conference on Manufacturing Systems 2012, Athens Greece,vol3, pp. 394-399, 2012.

[9] K. Lokhande and M. Gopalakrishnan, "Analysis of the impact of process complexity on unbalanced work in assembly process and methods to reduce it," Master of Science Thesis, Royal Institute of Technology, Stockholm, 2012 